\title{
A MORPHOLOGICAL ANALYSIS OF DERIVATIONAL AND INFLECTIONAL MORPHEMES
}

\author{
${ }^{1}$ Tri Indah Rezeki, ${ }^{2}$ Rakhmat Wahyudin Sagala \\ ${ }^{1}$ STKIP Budidaya Binjai \\ trindah.rizky@gmail.com \\ ${ }^{2}$ Universitas Muhammadiyah Sumatera Utara \\ rakhmatwahyudin@umsu.ac.id
}

\begin{abstract}
Morphological analysis is the main areas in studying vocabulary. Morphological analysis itself is analysis that is breaking a word into its elements (root, prefix and suffix). This study was conducted to analyze the use of derivational and inflectional morphemes in the song lyric "A thousand years" by Christina Perri. This study applied descriptive qualitative research which researchers found out the derivational and inflectional suffixes from the words in "A thousand years" lyric. The results of analyzing data were found in this study are derivational morphemes -ly consist of 2 words and inflectional morphemes $-\mathrm{s}$ plural, $-\mathrm{s}$ third singular person present tense, -ed past tense, -ing progressive and -er comparative consist of 57 words.
\end{abstract}

Keywords: Morphology; Morpheme; Derivational suffix, Inflectional suffix

\section{INTRODUCTION}

Language is one of important thing in human society's life to communicate each other (Sagala, 2019). Therefore, we must be able to master the language and its elements such as vocabulary, structure, and so forth. The language itself consists of two aspects namely form and meaning.

Morphological analysis is the main areas in studying vocabulary. Morphological analysis itself is analysis that is breaking a word into its elements (root, prefix and suffix). Meanwhile, derivational and inflectional morphemes are the part of morphological analysis. So, it is important for the students to study about derivational and inflectional suffixes. When the students are able to identify derivational and inflectional suffixes, they can develop their vocabulary because from just one word it can gain many words with different part of speech.
Morphology is the science of linguistics that studied the composition of a word grammatical which focuses on the word formation in producing the meaning grammatically. Verhaar (1990) states that morphology is the field of linguistics that studies the composition of part a word grammatically. Morphology includes in the field of linguistics that studies the morpheme and combinations. Besides, morphology is also the language structures that include words and parts or words that is called as morpheme.

Speakers of a language can recognize that word forms may include a number of units. For example, we can make out that English word forms like plays, player, played and playing can be split into pieces; they are made up of one unit play, and a number of other elements like -s, -er, -ed and -ing. All these elements are called morphemes. It is the minimal units of meaning 
or grammatical function that are used to form words (Lieber, 2009).

Derivational and inflectional morphemes are part of morphological analysis. Derivational morphemes are used to create new words or to make words of a different grammatical class from the stem (Yule, 2010). For example, the addition of the derivational morpheme -ize changes the adjective normal to the verb normalize. Similarly, we can derive the adjectives helpful and helpless by adding the derivational morphemes -ful and less to the noun help.

While inflectional morphemes are used to show some aspects of the grammatical function of a word. We use inflectional morphemes to indicate if a word is singular or plural, whether it is past tense or not, and whether it is a comparative or possessive form. In fact, inflection exists in many languages, but compared to other languages of the world there is relatively little inflection in English. Today there are only eight inflectional morphemes in English, as shown in the table below:

Table 1. Inflectional Morphemes

\begin{tabular}{ccl}
$\begin{array}{c}\text { English } \\
\text { Inflectional } \\
\text { Morphemes }\end{array}$ & $\begin{array}{c}\text { Added } \\
\text { to }\end{array}$ & Examples \\
\hline -s plural & Nouns & $\begin{array}{l}\text { She has got } \\
\text { two guitars }\end{array}$
\end{tabular}

\begin{tabular}{|c|c|c|}
\hline -s possessive & Nouns & $\begin{array}{l}\text { Khanza's } \\
\text { hair is long }\end{array}$ \\
\hline -er comparative & Adjective & $\begin{array}{l}\text { Khanza has } \\
\text { longer hair than } \\
\text { Taqiyya }\end{array}$ \\
\hline -est superlative & Adjective & $\begin{array}{l}\text { Khanza has the } \\
\text { longest hair }\end{array}$ \\
\hline $\begin{array}{l}\text {-s third singular } \\
\text { person present } \\
\text { tense }\end{array}$ & Verbs & $\begin{array}{l}\text { Khanza plays a } \\
\text { doll }\end{array}$ \\
\hline -ed past tense & Verbs & $\begin{array}{l}\text { Khanza played a } \\
\text { doll }\end{array}$ \\
\hline -ing progressive & Verbs & $\begin{array}{l}\text { Khanza is playing } \\
\text { a doll }\end{array}$ \\
\hline $\begin{array}{c}\text {-en past } \\
\text { participle }\end{array}$ & Verbs & $\begin{array}{l}\text { She has taken a } \\
\text { doll }\end{array}$ \\
\hline
\end{tabular}

Derivational and inflectional morphemes are important to be explained. By knowing about the meaning of derivational and inflectional morphemes in any texts, the students can learn the English word and text easily and it makes more interest. Based on the phenomena above, the researchers are interested in conducting a study entitled A Morphological Analysis of Derivational and Inflectional Morphemes in the Song Lyric "A Thousand Years" by Christina Perri because this song is very popular and the content of the lyric is very beautiful to be heard in every single moment.

\section{METHOD}

This study applied a descriptive qualitative research. According to Gay n Airisian (2000) descriptive qualitative research involves collecting data in order to test hypothesis or to answer the question concerning the current status of the subject of the study. Ary (2006) added that descriptive qualitative research is a design to obtain information concern the current status phenomena. It is directed toward determining the nature of a situation as it exist at the time of the study. In qualitative research, the researcher is an actor to collect the data (Moleong, 2011).

The data of this study was gained from the song lyric of "A thousand years" which contain derivational and inflectional morphemes. Then, the data was analyzed based on types of derivational and inflectional morphemes by Yule (2000).

\section{RESULT AND DISCUSSION}

\section{a. Data Analysis of Derivational Morpheme}

Derivational morphemes are used to create new words or to make words of a different grammatical class from the stem (Yule, 2000). 
The data analysis of derivational morpheme can be seen in table 2 .

\section{Table 2. Data Analysis of Derivational Morpheme}

\begin{tabular}{ccccc}
\hline No. & Morpheme & Word & Analysis & Amount \\
\hline 1. & Derivational & Suddenly & $\begin{array}{c}\text { Sudden } \\
\text { (adjective) } \\
-\end{array}$ & 2 \\
& & $\begin{array}{c}- \\
\text { suddenly } \\
\text { (adverb) }\end{array}$ & \\
\hline \multicolumn{4}{c}{ Total } & \\
\hline
\end{tabular}

\section{b. Data Analysis of Inflectional Morpheme}

Inflectional morphemes are used to show some aspects of the grammatical function of a word. There are 8 types of inflectional morphemes namely $-\mathrm{s}$ plural, -s possessive, -er comparative, -est superlative, -s third person singular present tense, -ed past tense, -ing progressive and -en past participle. Based on the data, inflectional morpheme can be found in the lyric song.

Table 3. Data Analysis of Derivational Morpheme

\begin{tabular}{|c|c|c|c|c|}
\hline No. & Morpheme & Word & Analysis & $\underset{t}{\operatorname{Amoun}}$ \\
\hline 1. & Inflectional & Colors & -s plural & 2 \\
\hline 2. & & Promises & -s plural & 2 \\
\hline 3. & & Years & -s plural & 10 \\
\hline 4. & & Beats & $\begin{array}{c}\text {-s } 3^{\text {rd }} \\
\text { singular } \\
\text { person } \\
\text { present } \\
\text { tense }\end{array}$ & 1 \\
\hline 5. & & Stands & 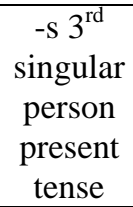 & 2 \\
\hline 6. & & Goes & $\begin{array}{c}-\mathrm{s} 3^{\text {rd }} \\
\text { singular } \\
\text { person } \\
\text { present } \\
\text { tense }\end{array}$ & 2 \\
\hline 7. & & Died & -ed past & 6 \\
\hline
\end{tabular}

\begin{tabular}{|c|c|c|c|}
\hline & & tense & \\
\hline 8. & Loved & $\begin{array}{l}\text {-ed past } \\
\text { tense }\end{array}$ & 10 \\
\hline 9. & Believed & $\begin{array}{l}\text {-ed past } \\
\text { tense }\end{array}$ & 4 \\
\hline 10. & Watching & $\begin{array}{c}\text {-ing } \\
\text { profressive }\end{array}$ & 2 \\
\hline 11. & Waiting & $\begin{array}{c}\text {-ing } \\
\text { profressive }\end{array}$ & 6 \\
\hline 12. & Standing & $\begin{array}{c}\text {-ing } \\
\text { profressive }\end{array}$ & 2 \\
\hline 13. & Closer & $\begin{array}{c}\text {-er } \\
\text { comparative }\end{array}$ & 8 \\
\hline
\end{tabular}

Based on the data analysis, it can be seen that there are two words of derivational morphemes in the lyric song and there are 57 words of inflectional morphemes which consist of $14-\mathrm{s}$ plural, $5-\mathrm{s}$ third singular person present tense, 20 -ed past tense, 10 -ing progressive and 8 -er comparative.

\section{CONCLUSION}

Derivational morpheme and inflectional morpheme are found in the song lyric of " $\mathrm{A}$ thousand years" by Christina Perri. The total number is 59 words which consists of 2 derivational morphemes and 57 inflectional morphemes.

\section{REFERENCES}

Airasian, P and L. R. Gay. 2000. Educational Research: Competencies for Analysis and Application Sixth Edition. New Jersey: Prentice Hall Inc.

Ary, D., Jacob, L., C., Rajavieh, A., Sorensen, C. 2006. Introduction to Research in Education. Canada, Thomshon Wodswort,

Lieber, Rochelle. 2009. Introducing Morphology. New York: Cambridge University Press. 
Moleong, L.J. 2011. Metodologi Penelitian Kualitatif. Bandung: Remaja Rosdakarya.

Sagala, Rakhmat Wahyudin. "LANGUAGE ACQUISITION PADA ANAK PERIODE LINGUISTIK." (2019): 8489.
Verhaar, J.W.M. 1990. Pengantar Linguistik Jilid 1. Yogyakarta: Gajah Mada. University Press.

Yule, George. 2010. The Study of Language. USA: Cambridge University Press 